\title{
Seroprevalence of Borrelia burgdorferi among the indigenous people (Orang Asli) of Peninsular Malaysia
}

\author{
Chee-Sieng Khor ${ }^{1}$, Habibi Hassan ${ }^{1,2}$, Nurul-Farhana Mohd-Rahim ${ }^{1,2}$, Josephine Rebecca Chandren ${ }^{3}$, \\ Siti-Sarah Nore ${ }^{1}$, Jefree Johari ${ }^{1}$, Shih-Keng Loong ${ }^{1}$, Juraina Abd-Jamil ${ }^{1}$, Jing-Jing Khoo ${ }^{1}$, Hai-Yen Lee ${ }^{1}$, \\ Brian L Pike ${ }^{4}$, Wong Li Ping ${ }^{3}$, Yvonne Ai-Lian Lim5, Sazaly Abubakar ${ }^{1,2}$ \\ 1 Tropical Infectious Diseases Research and Education Centre (TIDREC), University of Malaya, Kuala Lumpur, \\ Malaysia \\ 2 Department of Medical Microbiology, Faculty of Medicine, University of Malaya, Kuala Lumpur, Malaysia \\ ${ }^{3}$ Department of Department of Social and Preventive Medicine, Faculty of Medicine, University of Malaya, Kuala \\ Lumpur, Malaysia \\ 4 U.S. Naval Medical Research Center - Asia, Singapore \\ ${ }^{5}$ Department of Parasitology, Faculty of Medicine, University of Malaya, Kuala Lumpur, Malaysia
}

\begin{abstract}
Introduction: Lyme disease has been well-described in the North America and European countries. However, information is still very limited in the developing countries including Malaysia. The Orang Asli (OA), the indigenous people of Peninsular Malaysia reside mostly in the forest and forest fringe areas abundant with the vector for Lyme disease. Here, we described the seroprevalence of Borellia burgdorferi (B. burgdorferi) among the OA and demographic variables that could be associated with seroprevalence.

Methodology: A total of 16 OA villages distributed across 8 states in Peninsular Malaysia participated in this study. Sera obtained from 904 OA volunteers were screened for anti-B. burgdorferi IgG antibodies. ELISA results obtained and demographic information collected were analysed to identify possible variables associated with seroprevalence.

Results: A total of $73(8.1 \%)$ OA tested positive for anti-B. burgdorferi IgG antibodies. Among all the variables examined, village of residence $(\mathrm{p}=0.045)$ was the only significant predictor for seropositivity. High $(>10.0 \%)$ prevalence was associated with three OA villages. Those living in one particular village were 1.65 times more likely to be seropositive as compared to other OA villages. Age, gender, marital status, household size, level of education, monthly household income and occupation were not significant predictors for seropositivity.

Conclusion: Results of the present study support earlier findings that B. burgdorferi infection among Malaysians is currently under-recognized. Further studies will be needed at these locations to confirm the presence of Lyme disease among these populations.
\end{abstract}

Key words: Lyme disease; Borrelia burgdorferi; Malaysia; Orang Asli; ticks; infectious diseases.

J Infect Dev Ctries 2019; 13(5):449-454. doi:10.3855/jidc.11001

(Received 01 November 2018 - Accepted 26 March 2019)

Copyright $\odot 2019$ Khor et al. This is an open-access article distributed under the Creative Commons Attribution License, which permits unrestricted use, distribution, and reproduction in any medium, provided the original work is properly cited.

\section{Introduction}

The tick is an important human and animal disease vector, capable of harbouring a wide range of pathogenic microorganisms. Among the diseases transmitted by ticks, Lyme disease, a disease caused by the spirochetes from Borrelia burgdorferi (B. burgdorferi) sensu lato (s.l.) complex, is one of the most recognised tick-borne diseases in humans [1,2]. The disease typically manifests as a skin rash and infection often results in more severe complications involving the joints, heart, and nervous system. Proper diagnosis and treatment during the early phase is important in limiting the severity of the disease [3].
Lyme disease is endemic in more than 70 countries worldwide $[1,4]$. The United States alone records about 30,000 annual cases, but the actual number has been estimated to be as high as 300,000 cases [5]. High incidences of Lyme disease have also been reported in European countries with the highest annual number of cases recorded in Austria and Germany [2]. As surveillance efforts are often limited in most developing countries, the epidemiology of Lyme disease is not well known. In Malaysia, a previously conducted serological study found the presence of anti-B. afzelii $\mathrm{IgG}$ antibodies in $3.3 \%$ of patients and blood donors [6]. Since prevalence of Lyme disease is highly dependent on the abundance of its vector, the prevalence is 
expected to be higher in communities living in forested or semi-forested areas where ticks are abundant.

Ticks propagation is highly influenced by factors such as abundance of hosts, environmental temperature and environmental humidity. The abundant wildlife and the tropical climate of Malaysian forests are optimal for ticks [7]. Of the various species of ticks found in the Malaysian forests, the tick species capable of acting as a vector for Lyme disease, Ixodes granulatus, has previously been reported in various location across Peninsular Malaysia (Figure 1) [8-13].

The indigenous people of the Peninsular Malaysia, locally known as the Orang Asli (OA), form a minority population which comprises of only $0.58 \%$ of the total population of Malaysia [14]. Most Orang Asli reside in OA settlements which are often located in the forest or forest-fringe areas. The OA depend significantly on surrounding forests where they forage for wild fruits, ornamental plants, and wood products, and hunt wild animals as a source of income and food. These activities predispose them to tick bites and increase their risk for tick-borne diseases. Report of tick-borne diseases among these populations, however, has been scarce. Their remote locations and lack of appreciation of tickborne diseases could be among the reasons. In the present study, we investigated the seroprevalence of $B$. burgdorferi among this unique community and identify demographic variables that could influence the seroprevalence.

Figure 1. Participating OA villages and locations with known presence of I. granulatus.

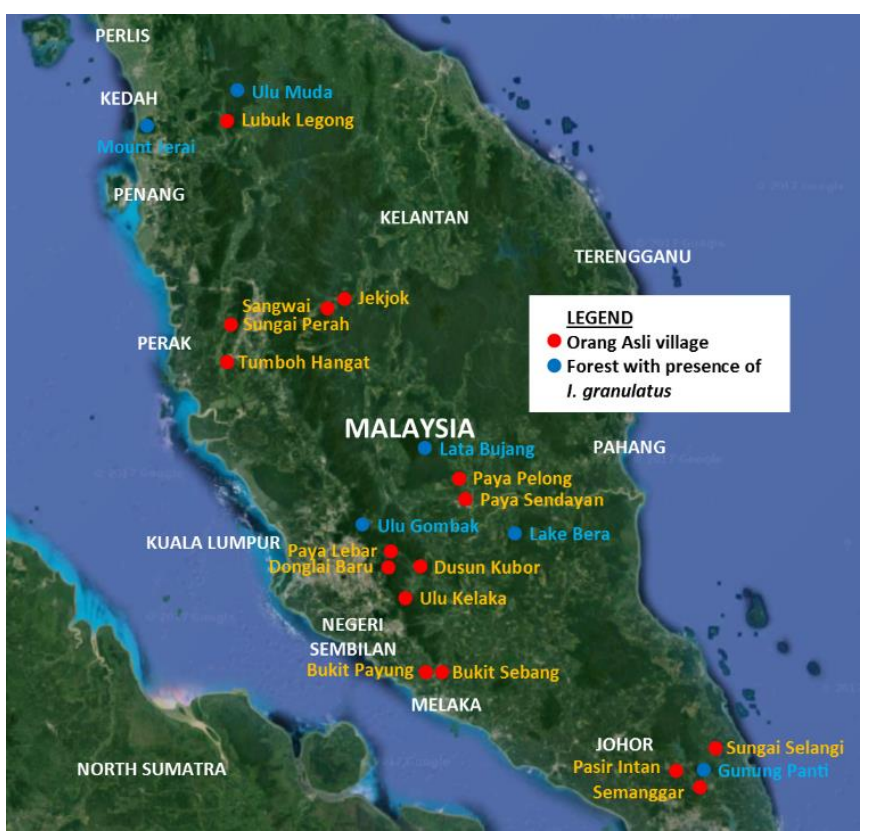

\section{Methodology}

Study Area and Sample Collection

The 16 OA villages from 8 states in Peninsular Malaysia were approved by JAKOA as study sites. These villages were Lubuk Legong (LL), Sungai Perah (SP), Tumboh Hangat (TH), Jekjok (JJ), Sangwai (SW), Paya Pelong (PP), Paya Sendayan (PS), Donglai Baru (DB), Paya Lebar (PL), Dusun Kubur (DK), Ulu Kelaka (UK), Bukit Payung (BP), Bukit Sebang (BS), Pasir Intan (PI), Semanggar (SM) and Sungai Selangi (SS) (Figure 1). Sampling activities conducted from July 2012 to June 2013 at the study sites resulted in 945 blood samples from healthy OA volunteers aged 5years of age and older. Approximately 5 to $10 \mathrm{ml}$ of blood was withdrawn from each participant through venipuncture using blood tubes with clot activator. The blood samples were centrifuged to separate serum from blood cells before the sera were aliquoted into storage tubes. All samples were stored at $-80^{\circ} \mathrm{C}$ prior to analysis. Adult volunteers were also given a questionnaire asking for their basic personal data, including marital status, education level, monthly household income, household size and occupation.

\section{Detection of anti-B. burgdorferi Ig $G$ antibodies}

The presence of $\mathrm{IgG}$ antibodies reactive against $B$. burgdorferi in serum samples was determined using the NovaLisa Borrelia burgdorferi IgG - ELISA (recombinant) kit (NovaTec Immunodiagnostica $\mathrm{GmbH}$, Dietzenbach, Germany). All procedures were performed strictly following the protocol provided by the manufacturer.

\section{Statistical analysis}

ELISA results and questionnaire data were analysed using the Statistical Package for the Social Sciences (SPSS) v24 (IBM Corp., New York, USA). Binary logistic regression was used to test the association between $B$. burgdorferi seropositivity, the dependant variable, with age and education level, gender, monthly household income, household size, marital status, village of residence and occupation as independent variables. Samples with equivocal results were excluded. Orang Asli villages with fewer than ten participants were excluded due to low participation rates.

\section{Results}

From the 16 approved study sites, 945 OA consented to participate in the study. Of the 16 study sites, BS and SS were excluded from the study due to the low participation. Samples with an insufficient 
volume for analysis were also excluded, along with samples with incomplete demographic data or equivocal ELISA results. In total, 904 sample results from 14 villages were considered for the study (Table 1). The mean age of participants was 23.2 years old (standard deviation $=16.0$, range $=5-83$ ) and 385 $(42.6 \%)$ of them were male. Serological detection performed found positive reaction for anti-B. burgdorferi $\mathrm{IgG}$ antibodies in $73(8.1 \%)$ of the serum samples. Among the 904 participants, 381 adult participants from $13 \mathrm{OA}$ villages responded to the questionnaire and were included in the following statistical analysis (Table 1). OA village (PP) was excluded due to low rate of questionnaire completion $(\mathrm{N}=4,16.7 \%)$. Most of the OA respondents $(86.6 \%)$ were married with household size of 5.5 (range $=1$ to 16) people on average. A large percentage of the OA $(42.3 \%)$ received formal education up to the primary school level (primary education) and were earning less than RM500 ( $\leq$ USD 125) a month (66.9\%). Most of the respondents were housewives $(44.7 \%)$ followed by plantation workers $(17.4 \%)$, odd-job workers $(8.8 \%)$, students (4.4\%), retirees \& unemployed (1.8\%) and others $(8.6 \%)$. Some $(14.3 \%)$ of the occupation were grouped as unknown because the respondent chose not to state their occupation in the questionnaire. Using marital status, household size, level of education, monthly household income, village of residence and occupation as independent variables, all variables tested were found not to be significant predictors $(\mathrm{p} \geq 0.05)$ for $B$. burgdorferi seropositivity except village of residence (Table 2). Among the villages, volunteers from TH (16.9\%), LL (14.5\%), SM (12.8\%) and DK (12.2\%) were found to have a high percentage of seropositivity (Table 1). Volunteers from TH were 1.65 times more likely to be seropositive as compared to other OA villages (TH vs non-TH).

\section{Discussion}

Based on the findings from this study, $8.1 \%(0.0 \%$ - $16.9 \%$ ) of the recruited OA were reactive to the recombinant $B$. burgdorferi antigens. These results are comparable to findings from similarly conducted studies in China (2.9\% - 14.9\%) [15], India (9.1\% -

Table 1. Seroprevalence of B. burgdorferi among the Orang Asli of Malaysia.

\begin{tabular}{|c|c|c|c|c|c|c|c|c|c|c|c|}
\hline \multirow[b]{2}{*}{ State } & \multicolumn{5}{|c|}{ Total participants, $N=904$} & \multicolumn{6}{|c|}{ Questionnaire respondents, $\mathrm{N}=381$} \\
\hline & $\begin{array}{l}\text { Village of } \\
\text { residence }\end{array}$ & $\mathrm{n}$ & Male (\%) & $\begin{array}{l}\text { Age, } \\
\text { mean } \\
\text { (SD) }\end{array}$ & $\begin{array}{l}\text { B. burgdorferi } \operatorname{IgG} \\
\text { positive, } \mathrm{n}(\%)\end{array}$ & $\begin{array}{l}\text { Respondent } \\
\text {, n (\%) }\end{array}$ & $\begin{array}{c}\text { Education level }{ }^{\mathrm{a}} \\
(\%)\end{array}$ & $\begin{array}{l}\text { Monthly household } \\
\text { income }, \text { MYR (\%) }\end{array}$ & $\begin{array}{l}\text { Married, } \\
\mathrm{n}(\%)\end{array}$ & $\begin{array}{c}\text { Household size, } \\
\text { mean (range) }\end{array}$ & $\begin{array}{l}\text { B. burgdorferi } \operatorname{IgG} \\
\text { positive, } \mathrm{n}(\%)\end{array}$ \\
\hline Kedah & LL & 83 & $42(50.6)$ & $\begin{array}{l}26.3 \\
(14.1)\end{array}$ & $12(14.5)$ & $51(61.4)$ & $\begin{array}{c}\text { Primary school } \\
(45.1)\end{array}$ & $<500(94.1)$ & $42(82.4)$ & $5.5(1-13)$ & $7(13.7)$ \\
\hline \multirow[t]{2}{*}{ Perak } & SP & 92 & $36(39.1)$ & $\begin{array}{c}28.4 \\
(16.7)\end{array}$ & $6(6.5)$ & $44(47.8)$ & $\begin{array}{c}\text { Primary school } \\
\text { (43.2) }\end{array}$ & $500-1000(54.5)$ & $38(86.4)$ & $4.7(2-10)$ & $2(4.5)$ \\
\hline & $\mathrm{TH}$ & 89 & $40(44.9)$ & $\begin{array}{c}22.7 \\
(15.2)\end{array}$ & $15(16.9)$ & $45(50.6)$ & $\begin{array}{c}\text { Primary school } \\
\text { (53.3) }\end{array}$ & $500-1000(51.1)$ & 34 (75.6) & $5.8(2-11)$ & $7(15.6)$ \\
\hline \multirow[t]{2}{*}{ Kelantan } & JJ & 69 & $26(37.7)$ & $\begin{array}{c}21.2 \\
(15.3)\end{array}$ & $3(4.3)$ & $31(44.9)$ & $\begin{array}{c}\text { Secondary } \\
\text { school (61.3) }\end{array}$ & $<500(64.5)$ & $30(96.8)$ & $5.5(2-12)$ & $1(3.2)$ \\
\hline & SW & 105 & $42(40.0)$ & $\begin{array}{c}19.6 \\
(15.2)\end{array}$ & $3(2.9)$ & $34(32.4)$ & $\begin{array}{c}\text { No formal } \\
\text { education }(52.9)\end{array}$ & $<500(85.3)$ & $31(91.2)$ & $5.9(3-13)$ & $1(2.9)$ \\
\hline \multirow[t]{2}{*}{ Pahang } & PP & 24 & $10(41.7)$ & $\begin{array}{l}16.0 \\
(14.8)\end{array}$ & $1(4.2)$ & $\mathrm{NA}^{\mathrm{b}}$ & $\mathrm{NA}^{\mathrm{b}}$ & $\mathrm{NA}^{\mathrm{b}}$ & $\mathrm{NA}^{\mathrm{b}}$ & $\mathrm{NA}^{\mathrm{b}}$ & $\mathrm{NA}^{\mathrm{b}}$ \\
\hline & PS & 97 & $46(47.4)$ & $\begin{array}{l}17.0 \\
(11.6)\end{array}$ & $7(7.2)$ & $26(26.8)$ & $\begin{array}{c}\text { Primary school } \\
\quad(53.8)\end{array}$ & $<500(76.9)$ & $21(80.8)$ & $5.8(2-9)$ & $1(3.8)$ \\
\hline \multirow[t]{2}{*}{ Selangor } & DB & 46 & $21(45.7)$ & $\begin{array}{c}22.1 \\
(19.0)\end{array}$ & $1(2.2)$ & 15 (32.6) & $\begin{array}{c}\text { No formal } \\
\text { education }(66.7)\end{array}$ & $<500(80.0)$ & $12(80.0)$ & $5.9(2-10)$ & $0(0.0)$ \\
\hline & PL & 47 & $18(38.3)$ & $\begin{array}{c}26.1 \\
(15.6)\end{array}$ & $3(6.4)$ & $26(55.3)$ & $\begin{array}{c}\text { Primary school } \\
\quad(46.2)\end{array}$ & $<1000(92.4)^{\mathrm{c}}$ & $22(84.6)$ & $6.1(3-11)$ & $3(11.5)$ \\
\hline \multirow[t]{2}{*}{$\begin{array}{l}\text { Negeri } \\
\text { Sembilan }\end{array}$} & DK & 123 & $55(44.7)$ & $\begin{array}{c}23.1 \\
(17.3)\end{array}$ & $15(12.2)$ & $42(34.1)$ & $\begin{array}{c}\text { Primary school } \\
\text { (54.8) }\end{array}$ & $<500(66.7)$ & $37(88.1)$ & $5.7(1-16)$ & $5(11.9)$ \\
\hline & UK & 51 & $21(41.2)$ & $\begin{array}{c}23.3 \\
(15.5)\end{array}$ & $2(3.9)$ & $25(49.0)$ & $\begin{array}{c}\text { Primary school } \\
(44.0)\end{array}$ & $<500(68.0)$ & $24(96.0)$ & $5.5(1-11)$ & $2(8.0)$ \\
\hline Melaka & BP & 20 & $4(20.0)$ & $\begin{array}{c}27.1 \\
(15.7)\end{array}$ & $0(0.0)$ & $15(75.0)$ & $\begin{array}{c}\text { Primary school } \\
\text { (53.3) }\end{array}$ & $<500(80.0)$ & $\begin{array}{c}15 \\
(100.0)\end{array}$ & $5.2(3-8)$ & $0(0.0)$ \\
\hline \multirow[t]{2}{*}{ Johor } & PI & 19 & $7(36.8)$ & $\begin{array}{c}29.2 \\
(14.6)\end{array}$ & $0(0.0)$ & $11(57.9)$ & $\begin{array}{c}\text { No formal } \\
\text { education }(45.5)\end{array}$ & $<500(63.6)$ & $9(81.8)$ & $4.2(1-7)$ & $0(0.0)$ \\
\hline & SM & 39 & $17(43.6)$ & $\begin{array}{c}31.5 \\
(19.4)\end{array}$ & $5(12.8)$ & $16(41.0)$ & $\begin{array}{c}\text { No formal } \\
\text { education }(43.8)\end{array}$ & $<500(68.8)$ & $15(93.8)$ & $5.3(3-7)$ & $1(6.3)$ \\
\hline Total & & 904 & $\begin{array}{c}385 \\
(42.6)\end{array}$ & $\begin{array}{c}23.2 \\
(16.0)\end{array}$ & $73(8.1)$ & $381(42.1)$ & $\begin{array}{c}\text { Primary school } \\
\text { (42.3) }\end{array}$ & $<500(66.9)$ & $\begin{array}{c}330 \\
(\mathbf{8 6 . 6})\end{array}$ & $5.5(1-16)$ & $30(7.9)$ \\
\hline
\end{tabular}

${ }^{a}$ Education level and Monthly household income are both categorical variable with more than 2 levels. Categories with highest percentage are displayed; ${ }^{b}$ Not included in the analysis due to low number of respondents $(\mathrm{N}=4)$; "The percentage of OA with annual household income of " $<500$ " and " $500-1000$ " are the same $(46.2 \%)$. 
Table 2. Univariate analysis on predictors for B. burgdorferi seropositivity.

\begin{tabular}{lcc}
\hline Variables & $\mathbf{N}$ & $\boldsymbol{p}$ \\
\hline Age & 904 & 0.804 \\
Gender & 904 & 0.227 \\
Education level & 381 & 0.531 \\
Household income & 381 & 0.740 \\
Household size & 381 & 0.419 \\
Marital status & 381 & 0.993 \\
Village & 904 & $\mathbf{0 . 0 4 5}$ \\
Occupation & 381 & 0.166 \\
\hline
\end{tabular}

Significant p-value $<0.05$ is bolded.

$17.8 \%$ ) [16] and Mongolia (1.9\% - 14.0\%) [17]. It was, however, lower in comparison to the seroprevalence studies conducted in selected-populations from Poland [18] and Sweden [19] where anti-B. burgdorferi IgG antibodies were found to range from $13.7 \%$ to $25.7 \%$. The observed inter-study differences in the seroprevalence could be attributed to a number of factors, foremost is the risk of contact with the disease vector [20]. The risk of contact, in turn, is influenced by the abundance of disease vectors in the area and activity pattern of the human host. Geographical and climatic factors such as abundance of animal hosts [21], temperature and humidity [22] significantly influence the abundance of ticks in an area. At the same time, outdoor activities, such as farming or foraging in forested areas, can increase the risk of tick-bites and the potential for exposure to B. burgdorferi. Occupation, the independent variable describing daily activities of the OA was, however, found to be statistically insignificant as a predictor for $B$. burgdorferi seropositivity (Table 2) despite some among the occupations described frequent plantations and forests (i.e. plantation workers and odd-job workers). The outcome of the statistical analysis might be caused by lack of sufficient statistical power in this study. Less than half ( $\mathrm{n}=381,42.1 \%)$ of the volunteers responded to the questionnaires and only a small percentage $(\mathrm{n}=$ $73,8.1 \%$ ) were tested positive for B. burgdorferi $\mathrm{IgG}$ antibodies. The three independent variables not affected by the low questionnaire completion rate, age, gender and village of residence, were analysed separately to allow the full use of data from 904 volunteers. In addition to these real epidemiological factors, some of the inter-study variability in seroprevalence may also be a function of the specificity of assays used across the different studies.

Lyme disease is predominantly caused by $B$. burgdorferi sensu stricto, $B$. garinii and $B$. afzelii. However, more than 20 new genospecies in $B$. burgdorferi s.l. complex have been discovered over the past decades and seven of them (B. bavariensis [23,24], $B$. bissettii, B. kurtenbachii [25], B. lusitaniae, B. mayonii [26], B. spielmanii and B. valaisiana) have exhibited evidence of being able to cause human infections [27]. B. burgdorferi sensu stricto,

B. garinii, B. afzelii, B. bavariensis and $B$. valaisiana were among the borrelia species found in circulating in China [28], Japan [29], Korea [8] and Taiwan [30]. The discovery of the new genospecies revealed a higher genomic variation among genospecies in B. burgdorferi s.l. complex which could potentially affect the accuracy of serological tests. Most of the existing serological tests however, were designed and formulated without being validated using the new genospecies. It is unknown if the serological tests can detect new Lyme disease causing genospecies or crossreact with non-Lyme causing genospecies [31]. Existing detection or diagnostic assays should be validated against all reported genospecies in $B$. burgdorferi s.l. complex to determine sensitivity and specificity of the assays. In addition, the ELISA kit used may produced false-positive result due to crossreactivity with Treponema pallidum, the causative agent for syphilis. Seroprevalence of syphilis among OA population remained unknown due to lack of serological data. As such, the extent of cross-reactivity caused by anti-Treponema pallidum IgG antibodies cannot be determined at this point.

Ultimately, clearly defining the true risk of $B$. burgdorferi exposure across regions and populations will require well-designed epidemiological studies with agreed upon standardized assays that take into account the environmental and behavioural variables outlined above.

\section{Conclusion}

The study described the seroprevalence of $B$. burgdorferi among OA of Peninsular Malaysia at 8.1\%. Village of residence was the only significant predictor for seropositivity. OA from TH village were most likely to be seropositive for B. burgdorferi. The distribution of B. burgdorferi s.l. genospecies especially among the $\mathrm{TH}$ population requires further investigation.

\section{Acknowledgements}

The authors would like to thank all volunteers, JAKOA and Orang Asli village chiefs for their cooperation and assistance in sample collection activities. This study is funded in parts by the U.S. Naval Medical Research Center - Asia (Work Unit Number D-1101) and the U.S. Department of State, Biosecurity Engagement Program (NAMRU: J-5502575053), University of Malaya Research Grant (UMRG: 
FL001-13HTM), University Research Grant 2018, Centre of Excellence (COE) Programs (RU008-2018).

\section{Ethics Statement}

The study protocol was approved by the Medical Ethics Committee of the University of Malaya Medical Centre, Malaysia (MEC Ref. No: 824.11). Permission was also obtained from the Department of Orang Asli Development (JAKOA) (reference number: JHEOA.PP.30.052 Jld. 6 (19)), a department under the Malaysian Ministry of Rural and Regional Development entrusted to oversee the affairs of the OA. Subjects or legal guardians of the subject consented to participate in this study.

\section{Author Disclosure Statement}

The authors declare that they have no competing interests. BLP is a U.S. military service member. This work was prepared as part of his official duties. The opinions and assertions contained herein are those of the author and are not to be construed as official or reflecting the views of the Department of the Navy, Department of Defense, or the U.S. Government. Furthermore, Title 17 U.S.C. $\$ 105$ provides that 'Copyright protection under this title is not available for any work of the United States Government.' Title 17 U.S.C. $\$ 101$ defines a U.S. Government work as a work prepared by a military service member or employee of the U.S. Government as part of that person's official duties.

\section{References}

1. Mead PS (2015) Epidemiology of Lyme disease. Infect Dis Clin North Am 29: 187-210.

2. Lindgren E, Jaenson TG (2006) Lyme borreliosis in Europe: influences of climate and climate change, epidemiology, ecology and adaptation measures. (No. EUR/04/5046250). Copenhagen: WHO Regional Office for Europe. Available. http://www.euro.who.int/_data/assets/pdf_file/0006/96819/E 89522.pdf. Accessed: 23 May 2019.

3. Begović-Kuprešanin V, Milanović M, Mikić D, Popović S, Hristović D, Rajić-Dimitrijević R, Takić-Radovanović T (2018) The influence of early antibiotic therapy on the clinical manifestations in patients with early Lyme. Srp Arh Celok Lek 146: 516-523.

4. Wu XB, Na RH, Wei SS, Zhu JS, Peng HJ (2013) Distribution of tick-borne diseases in China. Parasit Vectors 6: 119.

5. Kuehn BM (2013) CDC estimates 300000 US cases of Lyme disease annually. Jama 310: 1110-1110.

6. Tay ST, Kamalanathan M, Rohani MY (2002) Borrelia burgdorferi (strain B. afzelii) antibodies among Malaysian blood donors and patients. Southeast Asian J Trop Med Public Health 33: 787-793.

7. Ogden NH, Lindsay LR, Beauchamp G, Charron D, Maarouf A, O'Callaghan CJ, Waltner-Toews D, Barker IK (2004) Investigation of relationships between temperature and developmental rates of tick Ixodes scapularis (Acari: Ixodidae) in the laboratory and field. J Med Entomol 41: 622-633.

8. Masuzawa T, Fukui T, Miyake M, Oh HB, Cho MK, Chang WH, Imai Y, Yanagihara Y (1999) Determination of members of a Borrelia afzelii-related group isolated from Ixodes nipponensis in Korea as Borrelia valaisiana. Int J Syst Bacteriol 49 Pt 4: 1409-1415.

9. Mariana A, Zuraidawati Z, Ho TM, Kulaimi BM, Saleh I, Shukor MN, Shahrul-Anuar MS (2008) Ticks (Ixodidae) and other ectoparasites in Ulu Muda Forest Reserve, Kedah, Malaysia. Southeast Asian J Trop Med Public Health 39: 496506.

10. Khoo JJ, Ishak SN, Lim FS, Mohd-Taib FS, Khor CS, Loong SK, AbuBakar S (2018) Detection of a Borrelia sp. from Ixodes granulatus ticks collected from rodents in Malaysia. J Med Entomol 55: 1642-1647.

11. Paramasvaran S, Sani RA, Hassan L, Krishnasamy M, Jeffery J, Oothuman P, Salleh I, Lim KH, Sumarni MG, Santhana RL (2009) Ectoparasite fauna of rodents and shrews from four habitats in Kuala Lumpur and the states of Selangor and Negeri Sembilan, Malaysia and its public health significance. Trop Biomed 26: 303-311.

12. Madinah A, Fatimah A, Mariana A, Abdullah MT (2011) Ectoparasites of small mammals in four localities of wildlife reserves in Peninsular Malaysia. Southeast Asian J Trop Med Public Health 42: 803-813.

13. Mariana A, Mohd KB, Halimaton I, Suhaili ZA, ShahrulAnuar MS, Nor ZM, Ho TM (2011) Acarine ectoparasites of Panti Forest Reserve in Johore, Malaysia. Asian Pac J Trop Biomed 1: 1-5.

14. Bedford KJA (2009) Gombak hospital, the Orang Asli hospital: Government healthcare for the indigenous minority of Peninsular Malaysia. Indonesia and the Malay World 37: 2344.

15. Hao Q, Geng Z, Hou XX, Tian Z, Yang XJ, Jiang WJ, Shi Y, Zhan ZF, Li GH, Yu DS, Wang HY, Xu JG, Wan KL (2013) Seroepidemiological investigation of lyme disease and human granulocytic anaplasmosis among people living in forest areas of eight provinces in China. Biomed Environ Sci 26: 185-189.

16. Praharaj AK, Jetley S, Kalghatgi AT (2008) Seroprevalence of Borrelia Burgdorferi in North Eastern India. Med J Armed Forces India 64: 26-28.

17. Walder G, Lkhamsuren E, Shagdar A, Bataa J, Batmunkh T, Orth D, Heinz FX, Danichova GA, Khasnatinov MA, Wurzner R, Dierich MP (2006) Serological evidence for tick-borne encephalitis, borreliosis, and human granulocytic anaplasmosis in Mongolia. Int J Med Microbiol 296 Suppl 40: 69-75.

18. Zajac V, Pinkas J, Wojcik-Fatla A, Dutkiewicz J, Owoc A, Bojar I (2017) Prevalence of serological response to Borrelia Burgdorferi in farmers from eastern and central Poland. Eur J Clin Microbiol Infect Dis 36: 437-446.

19. Gustafson R, Svenungsson B, Gardulf A, Stiernstedt G, Forsgren M (1990) Prevalence of tick-borne encephalitis and Lyme borreliosis in a defined Swedish population. Scand J Infect Dis 22: 297-306.

20. Stafford KC, 3d, Cartter ML, Magnarelli LA, Ertel SH, Mshar PA (1998) Temporal correlations between tick abundance and prevalence of ticks infected with Borrelia burgdorferi and increasing incidence of Lyme disease. J Clin Microbiol 36: 1240-1244.

21. Ostfeld RS, Canham CD, Oggenfuss K, Winchcombe RJ, Keesing F (2006) Climate, deer, rodents, and acorns as determinants of variation in lyme-disease risk. PLoS Biol 4: e145.

22. Vail SG, Smith G (1998) Air temperature and relative humidity effects on behavioral activity of blacklegged tick (Acari: Ixodidae) nymphs in New Jersey. J Med Entomol 35: 10251028. 
23. Wilske B, Busch U, Eiffert H, Fingerle V, Pfister HW, Rossler D, Preac-Mursic V (1996) Diversity of OspA and OspC among cerebrospinal fluid isolates of Borrelia burgdorferi sensu lato from patients with neuroborreliosis in Germany. Med Microbiol Immunol 184: 195-201.

24. Margos G, Vollmer SA, Cornet M, Garnier M, Fingerle V, Wilske B, Bormane A, Vitorino L, Collares-Pereira M, Drancourt M, Kurtenbach K (2009) A new Borrelia species defined by multilocus sequence analysis of housekeeping genes. Appl Environ Microbiol 75: 5410-5416.

25. Picken RN, Cheng Y, Strle F, Picken MM (1996) Patient isolates of Borrelia burgdorferi sensu lato with genotypic and phenotypic similarities of strain 25015. J Infect Dis 174: 11121115.

26. Pritt BS, Mead PS, Johnson DKH, Neitzel DF, RespicioKingry LB, Davis JP, Schiffman E, Sloan LM, Schriefer ME, Replogle AJ, Paskewitz SM, Ray JA, Bjork J, Steward CR, Deedon A, Lee X, Kingry LC, Miller TK, Feist MA, Theel ES, Patel R, Irish CL, Petersen JM (2016) Identification of a novel pathogenic Borrelia species causing Lyme borreliosis with unusually high spirochaetaemia: a descriptive study. Lancet Infect Dis 16: 556-564.

27. Stanek G, Reiter M (2011) The expanding Lyme Borrelia complex--clinical significance of genomic species? Clin Microbiol Infect 17: 487-493.

28. Li M, Masuzawa T, Takada N, Ishiguro F, Fujita H, Iwaki A, Wang H, Wang J, Kawabata M, Yanagihara Y (1998) Lyme disease Borrelia species in northeastern China resemble those isolated from far eastern Russia and Japan. Appl Environ Microbiol 64: 2705-2709.

29. Takano A, Nakao M, Masuzawa T, Takada N, Yano Y, Ishiguro F, Fujita H, Ito T, Ma X, Oikawa Y, Kawamori F, Kumagai K, Mikami T, Hanaoka N, Ando S, Honda N, Taylor K, Tsubota T, Konnai S, Watanabe H, Ohnishi M, Kawabata H (2011) Multilocus sequence typing implicates rodents as the main reservoir host of human-pathogenic Borrelia garinii in Japan. J Clin Microbiol 49: 2035-2039.

30. Masuzawa T, Pan MJ, Kadosaka T, Kudeken M, Takada N, Yano Y, Imai Y, Yanagihara Y (2000) Characterization and identification of Borrelia isolates as Borrelia valaisiana in Taiwan and Kinmen Islands. Microbiol Immunol 44: 10031009.

31. Zajkowska JM (2014) Antibody-based techniques for detection of Lyme disease: a challenging issue. Antib Technol J 4: 33 44.

\section{Corresponding author}

Sazaly Abubakar

Department of Medical Microbiology, Tropical Infectious Diseases Research \& Education Centre, Faculty of Medicine, University of Malaya, 50603 Kuala Lumpur, MALAYSIA

Phone: +603-79676670

Fax: +603-79675757

E-mail address: sazaly@um.edu.my

Conflict of interests: No conflict of interests is declared. 